grateful for any living plants or seeds of $P$. farinosa, $P$. scotica, $P$. scandinavica, $P$. stricta and $P$. finmarchica from Great Britain, Europe and North and South America.

Department of Botany, University College,

$$
\text { E. W. Davies }
$$

Leicester. Oct. 8.

${ }^{2}$ Brunn, N. G., Sym. Bot. Upsal., 1 (1932).

${ }^{2}$ Wright-Smith, W., Truns. Roy. Soc. Edin. (1949).

\section{Habitat of Polycelis felina (= cornuta) and Crenobia alpina in the British Isles}

THE few text-books on freshwater biology which refer particularly to the British Isles regard Polycelis felina and Crenobia alpina as stenothermous, streamdwelling species. Beauchamp ${ }^{1}$, however, showed that C. alpina inhabited suitable shores of some Cumberland lakes during the winter; but he considered that summer temperatures were too high for their occurrence in lakes at this season. The generally accepted view is that in the British Isles these two species cannot establish themselves where the temperature exceeds $13^{\circ}-15^{\circ} \mathrm{C}$. in the case of $C$. alpina $a^{2,3}$ and $16^{\circ}-17^{\circ}$ C. for $P$. felina ${ }^{3}$. On the Continent, Theinemann ${ }^{4}$ considered that the widest range of $C$. alpina and $P$. felina was $0.7^{\circ}-15^{\circ} \mathrm{C}$. and $0.5^{\circ}-15 \cdot 75^{\circ} \mathrm{C}$. respectively. It has been reported several times from the Continent that Crenobia alpina is a permanent member of the fauna of Alpine and other mountain lakes where a suitable substratum occurs (for references see Beauchamp ${ }^{1}$ ).

During a survey of the freshwater triclads of the lochs on Islay (Argyll), Polycelis felina was found in six of them in July 1952 during a spell of warm weather when the average maximum air temperature, as recorded on Colonsay, was $20^{\circ} \mathrm{C}$. and the average $16^{\circ} \mathrm{C}$., following a June of average warmth. Its abundance varied from a small to an exceedingly large population (see table). Twenty-three lochs in all were examined, and of these eleven were judged to provide a stony, wave-washed shore suitable for $P$. felina. These lochs are listed in order of concentration of calcium ions in the accompanying table - the number of $P$. felina and the total triclad population ( $P$. nigra and/or $P$. tenuis) taken per unit hour of collecting is also recorded. It is clear that this supposedly typical stream species occurred in some lochs in great abundance, and in four was numerically the dominant species. There can be no question that here it formed a typical component of the lake fauna and was not restricted to areas near streams; there is no reason for supposing that it is not a permanent member. It is also interesting to note that $P$. felina reached its greatest abundance in the more calcareous lakes. According to Carpenter ${ }^{2}$, this is contrary to the view expressed by Bornhauser, who observed that this species was markedly absent from streams with a high lime content. The explanation, however, may lie in the interpretation of the term 'high'. Loch Finlaggin, and to a lesser extent Loch Gorm also, are exceptions to the calcium ion $P$. felina trend. The former had a relatively high population of $P$.tenuis, and competition may explain the absence of $P$. felina; while Loch Gorm had a shore of stones lying on sand which would be disturbed during wind action and become most harmful to softbodied triclads.

Considering now Crenobia alpina, this species was not recorded from the Islay lochs, but was collected

\begin{tabular}{|c|c|c|c|c|c|}
\hline Loch & $\begin{array}{c}\text { Calcium } \\
\text { (mgm./1.) }\end{array}$ & $\begin{array}{l}P \text { felina } \\
\text { (1 hr. col- } \\
\text { lecting) }\end{array}$ & $\underset{\text { triclads }}{\text { Total }}$ & $\begin{array}{l}\text { Ioch } \\
\text { type }\end{array}$ & $\begin{array}{l}\text { Height } \\
\text { above sea- } \\
\text { level (ft.) }\end{array}$ \\
\hline nam Ban & $1 \cdot 6$ & Nil & Nil & Bill loch & 350 \\
\hline Cam & $2 \cdot 8$ & Nil & 20 & Hill loch & 300 \\
\hline Ardnahoe & $2 \cdot 8$ & 81 & 162 & Hill loch & 200 \\
\hline nan Gillean & $4 \cdot 4$ & Nil & 248 & Hill loch & 300 \\
\hline Gerarch & $4 \cdot 8$ & Nil & Nil & Peaty & 250 \\
\hline Gorm & $8 \cdot 8$ & 8 & 16 & Coastal & 250 \\
\hline Skerrols & $9 \cdot 6$ & 140 & 216 & $\begin{array}{l}\text { sandy } \\
\text { Lowland }\end{array}$ & 50 \\
\hline Finlaggin & $15 \cdot 6$ & Nil & 210 & loch & $\begin{array}{r}75 \\
170\end{array}$ \\
\hline Lossit & 16.4 & 324 & 324 & Hill loch & 300 \\
\hline Cadharn & $19 \cdot 2$ & 346 & 442 & Hill loch & 230 \\
\hline Ballygrant & $23 \cdot 2$ & 228 & 264 & Hill loch & 230 \\
\hline
\end{tabular}

from Loch Baile à Ghobhain and Loch Fiart on Lismore Island, and from Loch Restil (Argyll) in July 1951. The former two are low-lying, calcareous lochs (calcium, $50 \mathrm{mgm}$./1.) and the triclads were taken from exposed, stony shores. In more sheltered bays, $C$. alpina was absent and Polycelis nigra occurred. Loch Restil is a small, lime-poor (calcium, $2.4 \mathrm{mgm}$./l.) hill loch at approximately $800 \mathrm{ft}$. above sea-level. At the time, the records were considered as examples of aberrant behaviour, perhaps due to the drying-up of streams. However, on the clearcut evidence of the Islay records for $P$. felina, they may be better regarded as examples of the lakedwelling habit of C. alpina in the British Isles.

It is generally considered that these two triclads are limited in their distribution by their stenothermy, or associated oxygen tension ${ }^{5}$. Examination of average maximum July air temperatures for the British Isles (1901-30) shows that Islay, by virtue of its maritime position, lies north of the $62^{\circ} \mathrm{F} .\left(16 \cdot 7^{\circ} \mathrm{C}\right.$.) isotherm; Lismore is $1^{\circ}-2^{\circ} \mathbf{F}$. warmer. Allowing for the lower temperature of lake water and the certainty of periods of average temperature greater than $16 \cdot 7^{\circ} \mathrm{C}$. (average annual maximum temperature for Islay, 1901-30, was approximately $22 \cdot 5^{\circ} \mathrm{C}$.), the habit may still fit with the physiological explanation, particularly in the case of $P$. felina. (It is hoped to arrange for water temperatures to be recorded in one of the Islay lochs during the summer.) Thus $P$. felina and perhaps $C$. alpina may be permanent lake-dwellers in the northern part of the British Isles, but confined to streams farther south. P. felina was recorded from a stony beach in Windermere during Àgust 1950, but during a period of heavy rainfall and near the entry of a stream.

Different varieties of $P$. felina have been described by Theinemann, and it will be interesting to compare the Islay loch specimens with stream-dwelling forms. Living collections of Islay material have been submitted to Mr. Anders G. Dahm, University of Lund, Sweden, who is working on the taxonomy and ecology of this species.

I am grateful to the Nature Conservancy for defraying expenses for the field-work, and to the Meteorological Office for supplying data of temperatures for Colonsay.

Department of Zoology,

University College of North Wales, Bangor. Oct. 25.

${ }^{1}$ Beauchamp, R. S. A., J, Anim. Ecol., 1, 175 (1932).

${ }^{2}$ Carpenter, K., J. Ecol., 16, 105 (1928).

${ }^{3}$ Macan, T. T,; and Worthington, E. B., "Life in Lakes and Rivers", 126 (Collins, London, 1951)

-Theinemann, A., Int. Rev. Bydrobiol. Biol., Supp. 4 (1912).

$s$ de Beaufort, L. F., "Zoogeography of the Land and Inland Waters" (Sidgwick and Jackson, London, 1951). 